\title{
The role of the associate dean in UK universities: distributed leadership in action?
}

\author{
Alan Floyd $^{1}$ (D) Diane Preston ${ }^{2}$ \\ Published online: 10 August 2017 \\ (C) The Author(s) 2017. This article is an open access publication
}

\begin{abstract}
This paper reports on findings from a Leadership Foundation for Higher Education funded project exploring the role of associate deans in UK universities. While the number of associate deans leading cross-curricular and inter-disciplinary initiatives appears to be on the increase, there has been very little research focusing on the exact nature of the role and its importance, or otherwise, in the leadership and management of universities. Drawing on mixed-methods data from 15 semi-structured interviews and a follow-up online survey $(n=172)$, this paper reports on how the role is defined and positioned in relation to university organisational structures and identifies what the similarities and differences are between associate deans working at traditional and modern universities. As the first national survey of the role, it is argued that this paper makes a significant and original contribution to knowledge. By drawing on the concept of distributed leadership, the paper also offers new theoretical insights into how different types of universities in the UK are responding to external pressures as a consequence of the fast-changing and increasingly complex sector environment.
\end{abstract}

Keywords Associatedeans · Distributed leadership - Mixed methods · Organisational structures · University leadership

\section{Introduction}

Over recent years, a number of interrelated factors including globalisation, massification, and marketisation have forced higher education institutions to review and reimagine what are often perceived as outdated organisational management structures (Blaschke et al. 2014), historically based on the traditional unit of the subject department (Bryman 2007b). One apparent solution

\section{Alan Floyd}

alan.floyd@ reading.ac.uk

1 Institute of Education, University of Reading, London Road Campus 4 Redlands Road, Reading RG1 $5 \mathrm{EX}, \mathrm{UK}$

2 Open University Business School, Milton Keynes, UK 
is to implement new 'distributed leadership' models - frequently based on themes and programmes rather than on academic departments - with the hope of being more flexible and efficient in an increasingly competitive and international market (Holt et al. 2014), while at the same time attempting to ensure and improve quality within the organisation (Flumerfelt and Banachowski 2011). These models have led to an increase in cross-disciplinary middle leadership roles in universities (Preston and Floyd 2016), an example of which is the position of associate deans in the UK which is the focus of this article.

As a middle leader positioned above the level of the department head, associate deans are often perceived to be involved in more strategic as opposed to operational duties, without perhaps having the necessary power and authority that is afforded to more formal roles such as the dean. However, as there has been very little previous research into the role, it is unclear whether these perceptions hold true. What is clear, though, from a brief search of university and recruitment web sites over recent times (such as www.jobs.ac.uk) is that the number and type of associate dean roles in the UK are growing. While there have been some previous small scale research into the role in the UK (for example, Preston and Price 2012) and Australia (for example, Pepper and Giles 2015), there appear to be no large scale studies in this area. Consequently, several questions remain unanswered: How are associate deans positioned within university structures? What is the focus of their role? And what are the role similarities and differences between different types of institutions; for example, those working in traditional, research-led institutions compared with those working in more modern, vocationally focused universities? Given the perceived cultural divergence between these two types of universities in the UK, it is reasonable to suggest that the role may be dissimilar due to differences in organisational values surrounding leadership practices, perhaps with modern universities aligning themselves more to New Public Management ideologies and traditional universities favouring more collegial ways of working (Floyd 2016). Thus, there is a need for research to explore the exact nature of the role and its importance, or otherwise, in the leadership and management of universities in a national context.

The purpose of this paper is to fill this knowledge gap by reporting on data from a Leadership Foundation for Higher Education funded project investigating the role of associate deans across the UK. The aim of the project was to explore how the role of associate deans was defined, perceived, and experienced across a range of universities in order to highlight and disseminate models of good practice, identify challenges, and make recommendations for improved policy and practice. While aspects of the study are explored elsewhere, for example associate deans' leadership development needs (Preston and Floyd 2016), the specific purpose of this paper is to provide the 'big picture' findings of the project. The research questions addressed here are:

RQ1 How is the role of associate deans in the UK positioned in relation to university organisational structures?

RQ2 What are the similarities and differences between associate deans working at traditional (research-led) and more modern universities (former polytechnics)?

In evaluating this increasingly prevalent but under-researched role, it is hoped that a more thorough understanding of the position will emerge which is important for policy-makers, senior leaders, and researchers. Such research, for example, could improve our understanding of how the role contributes to the successful leadership of higher education institutions in a time of increasing global uncertainty and rapidly shifting organisational priorities. It could also 
help in the selection processes of new associate deans and could allow for more informed career advice for associate deans, both potential and in post. As the first national survey of associate deans to be undertaken in the UK, this research offers a significant and original contribution to knowledge. By drawing on the concept of distributed leadership, the paper also offers new theoretical insights into how different types of universities in the UK are responding to external pressures as a consequence of the fast-changing and increasingly complex sector environment.

Following this introduction, we outline the study's theoretical underpinnings. Then, we discuss the methodological choices that were made. Next, we present and discuss our findings. Finally, we offer some conclusions and highlight the implications of our work.

\section{Theoretical underpinnings}

\section{Distributed leadership}

The concept of distributed leadership has emerged as a response to the traditional 'heroic' or 'great man' theory of leadership which espouses that institutions can be led and transformed through the actions and behaviours of one person (Northouse 2013). As an alternative model, distributed leadership views leadership as a process which can, and should, be shared and dispersed throughout the organisation (Coleman 2005). Consequently, institutional leadership is seen more as 'the property of the collective rather than the individual' (Bolden et al. 2009, p. 259). While it could be argued that universities have always shared leadership and decisionmaking processes through faculties and department structures, in traditional hierarchical organisations the authority level of these groups has tended to be minimal, with such decisions being perceived as recommendations rather than final judgements (Owens and Valesky 2011). Distributed leadership views leadership as something that all staff are involved in not just those in positions of authority, the term being used to 'describe the type of leadership that is used in organizations that purposefully empower teams and individuals to make important decisions' (Owens and Valesky 2011, p. 214). As Bush (2011, p. 88) suggests, an important starting point in understanding the concept is to 'uncouple it from positional authority.' Similarly, van Ameijde et al. (2009, p. 765) contend that viewing leadership in this way challenges the idea that leadership is a solely vertical process occurring between two separate groups of people (the leader and their followers):

Distributed leadership challenges this view of leadership as a solely vertical process in which an individual leader is seen as the main source of influence which shapes the emergence of collective action, and instead focuses on the mechanisms through which diverse individuals contribute to the process of leadership in shaping collective action.

Beyond the notion of viewing distributed leadership simply as the delegation of decision rights to particular roles, adjacent work in organisation studies and linguistics suggest that leadership is discursive and that language and communication play an important and powerful role in the leadership process across all levels of an organisation (Wodak et al. 2011). The argument put forward by these authors is that in order to understand organisational leadership processes, it is necessary to explore leadership discourse, communication, and relational stances, and that leadership involves influence and meaning management distributed amongst several actors rather than necessarily just residing with one person in an appointed role 
(Fairhurst 2008; Fairhurst 2009). For example, Whittle et al. (2015) focused on the role of leaders and discursive processes in shaping sense-making during a period of strategic change in a multi-national corporation and found that by framing formal organisational structures differently by using specific language practices, such as speaking directly to staff who are not in senior leadership positions and communicating clearly how they have the potential to initiate change, staff can be mobilised to challenge existing authority relationships. The argument being made here is that by empowering staff through communication strategies which highlight the potential agency and power they hold, change can be made from within rather than from the top. The suggestion is that strategic communication and language techniques in distributed leadership practice can be crucial because 'it is primarily through the accounts, narratives and stories that organizational actors shape the interpretation of others' (Whittle et al. 2015 p. 380-381). This idea could be especially important when applied to the role of the associate dean in universities, who may hold leadership positions without any structural line management responsibilities or budgets and therefore may need to rely on their powers of persuasion and negotiation to enact change within and across their faculties.

Alongside an increase in distributed leadership practice, there have also been recent moves in higher education towards more horizontal and cross-faculty thematic leadership, mirroring the shift towards more interdisciplinary research and teaching practices. These shifts acknowledge that 'more parties may have more shared influence on their colleagues, above and beyond traditional formally and vertically designated leader-follower influence relationships' (Holt et al. 2014, p.383). The possible consequences of moving away from traditional vertical leadership models based on departments and disciplines, each with their associated 'tribes and territories' (Becher and Trowler 2001), to more cross faculty or cross-institutional models have yet to be fully explored, but may include shifts in academic identities for both leaders and the led; more project-based leadership practices involving more than one discipline, and a possible subsequent increase in accountability issues, especially when budgets are large but formal line management responsibilities are few. The research presented here aims to examine some of these key issues.

While many view the move to distributing leadership in higher education through crossinstitutional, interdisciplinary teams and projects as a panacea for the complexities of modern times, there are others who perceive it pejoratively and take a more critical stance. These authors argue that such shifts are a consequence of growing structural similarities or isomorphism between the public sector and the private sector, as Blaschke et al. (2014, p. 711-712) explain:

Stagnating public funding, increasing student enrolments, and a rise in both competition and cooperation with industrial research have forced universities to find new ways of organizing and governing higher education...In order to cope with inherent organizational change, more and more universities adopt business-like leadership and management styles at the expense of collegial governing practices...

It is argued that such isomorphism, linked to neo-liberal reforms and the increasing marketization of the education system, poses a threat to traditional academic identities built on the notion of discrete academic disciplines:

In an emerging example of structural isomorphism, the public sector is being encouraged to adopt some of the structural forms of the private sector, with alliances, distributions, synergies, hybrids and networks all to the fore. Former departments dissipate into 
ephemeral configurations, their members seeking safe harbour for their out-moded professional identities (Hartley 2009, p. 139).

Key questions arise from this work which are relevant to this study: What role does the associate dean have in leading and managing higher education institutions in this seemingly contradictory landscape? And what are the differences and similarities between associate deans working in different types of institutions such as those in traditional, research-led institutions compared with those that are more modern and vocationally focused?

While research on distributed leadership is well established in the literature on schools (see, for example, Gronn 2008; Lumby 2013; Mayrowetz 2008; Spillane et al. 2007; Torrance 2013; Woods et al. 2004), with Lumby (2013, p. 581) referring to it as 'the theory of choice for many', there has been surprisingly little research on this topic in the higher education sector (Bryman 2007b). This is the case even though, as previously argued, the notion of 'distributing leadership' in universities has become increasingly popular (Bolden et al. 2009; Floyd and Fung 2017). Concurring, Bianchini et al. (2014, p. 558) identified that more work is needed in this area:

It is clear from the literature that distributed leadership initiatives within the academy have been few and far between, and that those that have been documented have failed to show how such leadership can be learned and practised.

Accordingly, although the practice of distributing leadership is widespread across the sector, associated issues such as problems with accountability and power (Bolden et al. 2008; Corrigan 2013), differences between delegation and real authority (Owens and Valesky 2011), tensions between isomorphism and its perceived negative effect on academic values and identities (Blaschke et al. 2014; Hartley 2009), and links to discursive leadership practices (Fairhurst 2008; Fairhurst 2009; Whittle et al. 2015; Wodak et al. 2011) have not been sufficiently addressed. It is these key issues that this article seeks to explore.

\section{Methods}

To answer our research questions, we used a two-staged, mixed-methods approach, with the whole study 'embedded' within a constructivist framework (Cresswell 2014). In adopting this approach, we view experiences as being socially constructed and perceived differently by individuals depending on a range of cultural, historical, and situational factors (Punch 2014). Specifically, we used an exploratory, sequential mixed-methods design (Cresswell 2014) where qualitative data are gathered and analysed first, before quantitative data are collected from a larger sample size.

\section{Stage 1-interviews}

In stage one, we conducted qualitative research undertaking interviews with 15 associate deans from five different institutions using purposive sampling (Bryman 2012) to identify appropriate participants. More precisely, a stratified purposeful sampling approach was used to help illustrate subgroups of associate deans (e.g. female, male, specific role focus) and help facilitate comparisons between these subgroups (Gall et al. 2007; Miles and Huberman 1994). As one of the aims of the study was to compare results between traditional (research- 
Table 1 Interview participants

\begin{tabular}{lll}
\hline Pseudonym & Institution type & Role focus \\
\hline Bruce & Post-1992 & Strategy and development \\
Isobel & Post-1992 & Quality enhancement \\
Laura & Post-1992 & Student experience \\
Michael & Post-1992 & Student experience \\
Richard & Post-1992 & Quality enhancement \\
Steven & Post-1992 & Student experience \\
Tony & Post-1992 & Operation and performance \\
& & management \\
William & Post-1992 & Quality enhancement \\
Alex & Pre-1992 & Teaching and learning \\
Chris & Pre-1992 & Teaching and learning \\
Claire & Pre-1992 & Research \\
David & Pre-1992 & Teaching and learning \\
Peter & Pre-1992 & Teaching and learning \\
Phil & Pre-1992 & Research \\
Whitney & Pre-1992 & Teaching and learning \\
\hline
\end{tabular}

led) and more modern universities (former polytechnics), each institution was categorised as either a 'pre-1992' or 'post-1992' University: in the UK, former polytechnics and colleges of higher education were given university status in 1992, which leads to the phrase being understood as a simplistic but important distinction between university types in the country. The original aim was to interview four associate deans from four different universities (two pre- and two post-1992 institutions). However, we were only able to access three participants from each of the two pre-1992 universities chosen in the original sample. Fortunately, we were able to recruit one more participant from another pre-1992 university within the time scales of the project, so we ended up with 15 participants overall (seven from pre- and eight from post1992 institutions). The sample contained male $(n=11)$ and female $(n=4)$ staff with a range of ages, levels of experience, and discipline backgrounds. Table 1 shows the interview participants together with the institution type and role focus.

The research was conducted following ethical guidelines set out by the British Educational Research Association (BERA 2011): before data collection began, we applied for and gained full ethical approval and drew up detailed information sheets and consent forms; in order to ensure anonymity for respondents, pseudonyms have been used throughout.

Interview participants were invited to take part via email. Originally, we wanted to interview a similar number of associate deans in each institution covering a range of foci; however, in the end, our sample consisted of those associate deans who agreed to be interviewed. This meant that we interviewed fewer associate deans with responsibility for research than we would have liked. In fact, as can be seen from Table 1, we only managed to recruit two participants with this particular focus and they were both from pre-1992 institutions. Each participant was interviewed for approximately 1 hour and interviews were recorded and transcribed. The interviews were based on a semi-structured schedule-linked to our research questions and developed from a literature review - and included questions on how the role related to their institution's management structures and their experiences of being an associate dean. The schedule was peer reviewed before use by associate deans at each of the researchers' institutions. The interview data collected were analysed using thematic analysis techniques outlined by Lichtman (2013). These included reading and coding each transcript by using gerunds and by keeping the codes active and as close to the original statements as 
possible (Charmaz 2006), merging and reflecting on these codes to form larger categories and emerging conceptual themes, and then further developing these themes by comparing and contrasting them to the reviewed literature and theoretical framing of the study. An example of this process is shown in Table 2.

\section{Stage 2-questionnaire}

In order to examine whether the findings from stage 1 were indicative of associate deans' perceptions and experiences in a wider range of universities and to compare and contrast data between a larger number of pre-and post-1992 institutions, in the second stage of the project, we undertook a survey of associate deans using an online questionnaire (Survey Monkey) which was based on themes and issues emanating from the first stage of the project. The questionnaire was developed following guidelines put forward by Gehlbach and Brinkworth (2011) and subject to an initial peer review followed by a full piloting exercise involving associate deans in the two researchers' universities. Subsequently, an invitation and link to the survey were sent out via email to 472 associate deans across the UK (England, Scotland, and Wales only). Participant names were gleaned from websites and phone calls to HR departments. In total, 172 associate deans completed the survey giving a response rate of $36 \%$, although not all of these respondents answered every question. In line with the study's methodological framework, and as this was not a random sample, the survey results were analysed using descriptive (rather than inferential) statistics and cross tabulated to compare data from those who were associate deans in pre-1992 universities with those from post-1992 universities.

The survey was completed by 71 female associate deans (42\%) and 97 male associate deans (58\%) with four participants not answering this question. One hundred four $(59 \%)$ were from pre-1992 universities and $68(41 \%)$ from post-1992 universities. As shown in Table 3, the survey participants came from a range of faculty areas and academic disciplines with 31 participants ticking 'other' in response to this question. These participants tended to work in large faculties that had more than one distinct focus, for example, 'Education, Arts and Business' and 'Arts, Humanities and Social Sciences'. One hundred eleven (65\%) of the survey respondents had been in the role between 1 and 5 years, with $63(37 \%)$ having been in the role between 3 and 5 years, and 24 (14\%) being in the role for over 5 years.

The findings from both stages of the study have been combined and organised thematically and are presented in the following section.

\section{Findings}

\section{Focus and purpose of the role}

The interview and survey data suggest that associate deans perform a range of functions within UK universities, each with a particular focus. As shown in Tables 1 and 5, of the 16 interviewees were associate deans with responsibility for Teaching and Learning, 3 were responsible for Quality Enhancement, 3 for Student Experience, 2 for Research, 1 had the title of Associate Dean for Operation and Performance Management, and 1 for Strategy and Development. The majority of survey respondents were associate deans with responsibility for Teaching and Learning $(51 \%, n=68)$ while 39 (29\%) were associate deans for research, 17 
Table 2 Example of thematic analysis

\begin{tabular}{|c|c|c|}
\hline Initial codes & Themes & Concepts \\
\hline $\begin{array}{l}\text { Lacking authority } \\
\text { Being consultative }\end{array}$ & Leading without formal authority & Discursive leadership (Fairhurst 2008) \\
\hline $\begin{array}{l}\text { Negotiating with staff } \\
\text { Developing relationships } \\
\text { Influencing colleagues }\end{array}$ & Leadership through communication & $\begin{array}{l}\text { Relational approaches to management } \\
\text { development (Preston and Floyd 2016) }\end{array}$ \\
\hline
\end{tabular}

(13\%) associate deans for External Relations, and 10 (8\%) associate deans with responsibility for Strategy. Cross tabulations showing differences between pre-and post-1992 institutions are shown in Table 4.

What was clear from the responses to this question in the survey, however, was that a number of associate deans had responsibilities that were not easily defined within these umbrella terms with 42 respondents identifying other areas that they were responsible for including finance and planning, processing systems, postgraduate research, business development, admissions, marketing and recruitment, regulations and policy, student employability, enterprise, internationalisation, infrastructure, and social responsibility. The survey data also suggest that the majority of associate deans work both within their faculty and across the university as a whole. For example, as shown in Table 4, 99 respondents (60\%) said that their position was a joint faculty/university role.

Some of the interviewees explained how their role was explicitly linked to an espoused policy shift towards a more distributed leadership model within their institution. For example, one associate dean (AD) explained how his role fitted into this new structure:

...the whole point about the restructuring in the university has been about transformative leadership and distributed leadership. And although we focused on people in the faculty executive, that idea of distributed leadership goes down to the level of programme leads. Programme leads are meant to exercise leadership functions...In order to facilitate that, just after restructuring the university put on a long programme in terms of what's transformative leadership all about. We were each assigned coaches so we could take along examples of how things were working etc, etc. ... just to try and inculcate people with what the idea of distributed leadership really does mean and what transformative leadership means.

Table 3 Survey sample-academic discipline

\begin{tabular}{|c|c|c|c|c|c|c|}
\hline \multirow[t]{2}{*}{ Discipline } & \multicolumn{2}{|c|}{ Pre-1992 } & \multicolumn{2}{|c|}{ Post-1992 } & \multicolumn{2}{|c|}{ Total } \\
\hline & $n$ & $\%$ & $n$ & $\%$ & $n$ & $\%$ \\
\hline Life Sciences/Medicine & 27 & 16 & 8 & 5 & 35 & 20 \\
\hline Business & 12 & 7 & 20 & 12 & 32 & 19 \\
\hline Social Sciences & 19 & 11 & 10 & 6 & 29 & 17 \\
\hline Physical/Natural Sciences & 13 & 8 & 8 & 5 & 21 & 12 \\
\hline Humanities & 13 & 8 & 3 & 2 & 16 & 9 \\
\hline Arts & 5 & 3 & 3 & 2 & 8 & 5 \\
\hline Other & 15 & 9 & 16 & 9 & 31 & 18 \\
\hline
\end{tabular}

Percentage totals may not equal $100 \%$ because of rounding 
Table 4 Focus and positioning of role

\begin{tabular}{|c|c|c|c|c|c|c|}
\hline \multirow[t]{2}{*}{ Answer options } & \multicolumn{2}{|c|}{ Pre-1992 } & \multicolumn{2}{|c|}{ Post-1992 } & \multicolumn{2}{|c|}{ Total } \\
\hline & $n$ & $\%$ & $n$ & $\%$ & $n$ & $\%$ \\
\hline \multicolumn{7}{|l|}{ Focus of role } \\
\hline Teaching and Learning & 43 & 32 & 25 & 19 & 68 & 51 \\
\hline Research & 24 & 18 & 15 & 11 & 39 & 29 \\
\hline External Relations & 7 & 5 & 10 & 7 & 17 & 13 \\
\hline Strategy & 5 & 4 & 5 & 4 & 10 & 8 \\
\hline \multicolumn{7}{|l|}{ Role positioning } \\
\hline Mainly a joint faculty/University role & 67 & 41 & 32 & 19 & 99 & 60 \\
\hline Mainly a within-faculty role & 29 & 18 & 34 & 21 & 63 & 38 \\
\hline Mainly a cross-University role & 2 & 1 & 1 & 1 & 3 & 2 \\
\hline
\end{tabular}

Percentage totals may not equal $100 \%$ because of rounding

Others discussed how they felt that their 'distributed leadership' role provided a link between senior leaders and other academics. For example, one said:

It's to keep the Dean honest. And I don't mean that in a derogatory way but at the most senior levels of management you become very detached from what's actually going on on the ground. Certainly when the Associate Dean role was created one of my colleagues said we just have to accept that we are the Dean's eyes and ears on planet earth and I thought that was quite a good way of summarizing a lot of the role. So, I think we're an important interface between senior mangement and staff who are actually delivering for students. I do think we play an important role in ensuring that what is strategically seen as desirable is actually deliverable and can be operationalised...

And another commented on the 'distributed' leadership structure of their organisation down to programme level, but highlighted how difficult this model was in practice:

The most challenging thing is leading, leading heaps of people, who are very, very difficult to interface with, if at all. So how do you take them with you, like associate lectures or module leaders, when you're so remote from them? You can, there are models of distributed leadership, and that's what we try and do. So, you have program leads, you have someone on portfolios, and then you have a coordinator for those portfolios and program teams. But there are a lot of links that can get broken... if you're leading something you need to understand what the goal is, what the division is, and if they're part of it, and if you're part of it, and that's very hard.

These findings suggest that introducing the role of associate deans is seen as an important step by institutions in helping to 'distribute' leadership functions within a university, providing a perceived crucial link between senior leaders and academic staff, but that such leadership distribution is not a simple or easy process.

The interviewees were also keen to point out that while their roles encompassed many activities, with one explaining 'in reality it is sort of everything including walking around with a dustpan and brush metaphorically sweeping up after the Dean or sweeping up after this, that or the other...'; their role was very strategic in nature, including working across faculties and institutions. From the survey data, it was clear that the strategic nature of the role was also seen as very important, both across the faculty and across the university, with $94 \%$ agreeing that one of the main purposes of the role was linked to strategic development across the faculty and 
$83 \%$ agreeing that another was linked to strategic development across the university as opposed to only $60 \%$ who agreed that one of the main purposes of the role was linked to managing resources and just $42 \%$ who agreed that the management of staff was one of the role's main purpose. While the importance of the strategic purpose of the role appears to be broadly similar across both types of institutions, the answer to this question demonstrates some key differences between the two types of institutions in relation to the management of staff, which was perceived as a main purpose by more associate deans in post-1992 institutions than pre-1992 institutions. These results are shown in Table 5.

In answer to the question, 'to what extent have you been able to define the Associate Dean role?', the consensus amongst those interviewed appeared to be that they were given some scope to define what they might do, for example, how they might operationalise strategic demands and projects, but that was within the parameters of what was possible and what needed doing as the following examples show:

Not quite as much (flexibility) as I would like to because I think things are often overtaken by events and I think people ask you this occasionally, what are you going to do with the role?

There's a job description that lays out responsibilities, but I suppose how you define it is as what you give, how you divide up your time between those roles they seem to have equal hierarchy status in job description. And to some extent you're not free to do that, because there are certain things that need doing.

Even if respondents felt they had relatively little scope in defining what the associate dean's role might be, there was some room in, as one put it, 'defining how you are going to make that role work'. However, both the definition and actual undertaking of the role was felt to be 'often taken over by events'. It appeared that the role required flexibility and some degree of autonomy to make decisions from the dean if it was to work well.

Another theme that emerged from the interview data was a sense that in some cases, it was only the associate dean group themselves who had a clear sense of what they did - to others it was not always clear. Indeed, several associate deans felt that their role was not fully understood by other colleagues. One lamented:

If still not sure everybody throughout the university understands what the role is ... it's fairly easy to latch onto what a department head is ... this other bloke (the Associate Dean) does all sorts of different things and if it's not specifically research or teaching, then it must be his fault. And then there's the question, 'what do you do then?'

Other comments in the interviews suggested that the position may need clarification in some cases and that it was important for an institution to firmly establish, for administrators and other academics, the scope and purpose of the role:

So we often say amongst ourselves that other people outside the role don't understand it. The Dean really has very little concept of what our roles are about, which is a bit tricky for someone who is supposed to be your line manager.

I'm still not sure everybody throughout the university understands what the role is.

I sometimes think the work of a deputy dean often is quite invisible because sometimes you are the instigator, sometimes you are not. You are often not at the delivery end of things so it comes through somebody else but you have shaped it along its path, 
Table 5 Main purposes of role

\begin{tabular}{|c|c|c|c|c|c|c|}
\hline \multirow[t]{2}{*}{ Answer options } & \multicolumn{2}{|c|}{ Pre-1992 } & \multicolumn{2}{|c|}{ Post-1992 } & \multicolumn{2}{|c|}{ Total } \\
\hline & $n$ & $\%$ & $n$ & $\%$ & $n$ & $\%$ \\
\hline \multicolumn{7}{|c|}{ Strategic development across the faculty } \\
\hline Strongly Agree/Agree & 92 & 55 & 64 & 39 & 156 & 94 \\
\hline Neither Agree nor Disagree & 3 & 2 & 1 & 1 & 4 & 2 \\
\hline Disagree/Strongly Disagree & 2 & 1 & 4 & 2 & 6 & 4 \\
\hline \multicolumn{7}{|c|}{ Strategic development across the University } \\
\hline Strongly Agree/Agree & 87 & 52 & 53 & 32 & 140 & 84 \\
\hline Neither Agree nor Disagree & 7 & 4 & 10 & 6 & 17 & 10 \\
\hline Disagree/Strongly Disagree & 4 & 2 & 6 & 4 & 10 & 6 \\
\hline \multicolumn{7}{|l|}{ Management of resources } \\
\hline Strongly Agree/Agree & 48 & 29 & 49 & 30 & 97 & 60 \\
\hline Neither Agree nor Disagree & 22 & 13 & 6 & 4 & 28 & 17 \\
\hline Disagree/Strongly Disagree & 25 & 15 & 13 & 8 & 38 & 23 \\
\hline \multicolumn{7}{|l|}{ Management of Staff } \\
\hline Strongly Agree/Agree & 26 & 16 & 43 & 26 & 69 & 42 \\
\hline Neither Agree nor Disagree & 24 & 15 & 6 & 4 & 30 & 18 \\
\hline Disagree/Strongly Disagree & 45 & 28 & 19 & 12 & 64 & 39 \\
\hline
\end{tabular}

Percentage totals may not equal $100 \%$ because of rounding

whatever it is, we have taken an idea through to fruition and you are in the background of somebody doing that rather than demonstrating that you have taken the lead.

Some of these issues were also reflected in the survey data. For example, when survey participants were asked how well defined the role was within their institutions, 41 (24\%) participants in total indicated that their role was loosely or not at all well defined.

\section{Contracts and remuneration}

The interviewees were all on different contracts depending on which type of institution they worked in. For example, the majority of those in post-1992 universities held the role on a permanent basis and were in a promoted senior post with an associated enhanced salary. In contrast, however, the majority of interviewees in pre-1992 universities held the post on a fixed-term basis and were receiving an annual allowance. These differences were also reflected in the survey data. As shown in Table 6, the contractual nature of the role differed both between and within post- and pre-1992 universities with 50 participants (29\%) from post-1992 universities stating that their role was permanent alongside only 16 (9\%) from pre-1992 institutions. In contrast, 85 participants (50\%) from pre-1992 universities were on a fixedterm contract alongside only $19(11 \%)$ from post-1992 institutions.

As also shown in Table 6, there were a number of differences between how associate deans were remunerated for their role, with 19 participants (13\%) from pre-1992 universities and 59 (39\%) from post-1992 universities being in a paid, promoted senior post. Of those who received an allowance, $14(9 \%)$ received up to $£ 3000,38(25 \%)$ received between $£ 4000$ and $£ 6000,11(7 \%)$ receiving between $£ 7000$ and $£ 10,000$, and $9(6 \%)$ receiving over $£ 10,000$. The latter group were all from pre-1992 universities. From those that had ticked 'other' as an option here, there were 19 associate deans (11\%) who did not receive any remuneration for their role. These participants all worked in pre-1992 universities. 
Table 6 Contract type and remuneration

\begin{tabular}{|c|c|c|c|c|c|c|}
\hline \multirow[t]{2}{*}{ Answer options } & \multicolumn{2}{|c|}{ Pre-1992 } & \multicolumn{2}{|c|}{ Post-1992 } & \multicolumn{2}{|c|}{ Total } \\
\hline & $n$ & $\%$ & $n$ & $\%$ & $n$ & $\%$ \\
\hline \multicolumn{7}{|l|}{ Contract Type } \\
\hline Fixed Term & 85 & 50 & 19 & 11 & 104 & 61 \\
\hline Permanent & 16 & 9 & 50 & 29 & 66 & 39 \\
\hline \multicolumn{7}{|l|}{ Contract Length (fixed term contracts) } \\
\hline 2 years & 2 & 2 & 3 & 3 & 5 & 5 \\
\hline 3 years & 52 & 50 & 7 & 7 & 59 & 57 \\
\hline 4 years & 8 & 8 & 1 & 1 & 9 & 9 \\
\hline 5 years & 11 & 11 & 6 & 5 & 17 & 16 \\
\hline Other & 11 & 11 & 3 & 3 & 14 & 13 \\
\hline \multicolumn{7}{|l|}{ Role remuneration } \\
\hline Promoted senior post reflected in salary level & 19 & 11 & 59 & 34 & 78 & 45 \\
\hline Annual allowance of up to $£ 3 \mathrm{k}$ & 13 & 8 & 1 & 1 & 14 & 8 \\
\hline Annual allowance of between $£ 4 \mathrm{k}$ and $£ 6 \mathrm{k}$ & 33 & 19 & 5 & 3 & 38 & 22 \\
\hline Annual allowance of between $£ 7 \mathrm{k}$ and $10 \mathrm{k}$ & 9 & 5 & 2 & 1 & 11 & 6 \\
\hline Annual allowance of over $10 \mathrm{k}$ & 9 & 5 & 0 & 0 & 9 & 5 \\
\hline Other & 19 & 11 & 3 & 2 & 22 & 13 \\
\hline
\end{tabular}

Percentage totals may not equal $100 \%$ because of rounding

\section{Staff and budgetary management}

The majority of interviewees did not line manage any academic members of staff although most had responsibility for an administrator or administrative team. As set out in Table 7, 96 of those surveyed (59\%) also did not manage any academic staff directly. Of those that did, the majority (43\%) were only responsible for between one and five academic staff members. Similar results were found in relation to managing administrative staff with 100 participants $(60 \%)$ having no line management responsibilities over administrative staff. Of those that did, the majority $(70 \%)$ were responsible for between one and five staff members.

There were mixed responses as to whether the associate deans interviewed were responsible for a budget with approximately half of the sample saying that they were in charge of one. The survey revealed similar results (Table 6) with 105 associate deans (63\%) identifying as budget holders. Of those, $60 \%$ were managing a budget of $£ 50 \mathrm{k}$ or over, evenly split between pre-and post-1992 institutions.

\section{Leadership by negotiation}

In view of the fact that several interviewees perceived that they did not hold any real 'authoritative power' because they did not have a budget or line management responsibilities, many discussed how they had to achieve results using negotiation. For example, when one was asked what authority they felt they had in their role, they replied:

Well part of me says not a lot because ultimately it's very difficult for me to tell anybody to do anything because if they don't like it they'll just go to the Dean and it's the Dean ultimately who's job description says they have responsibility for dealing with these people. However, there are occasions, and I do try to be a consultative person and always like that way of working, down at the level of detail of individual staff, and 
Table 7 Staff and budgetary management

\begin{tabular}{|c|c|c|c|c|c|c|}
\hline \multirow[t]{2}{*}{ Answer options } & \multicolumn{2}{|c|}{ Pre-1992 } & \multicolumn{2}{|c|}{ Post-1992 } & \multicolumn{2}{|c|}{ Total } \\
\hline & $n$ & $\%$ & $n$ & $\%$ & $n$ & $\%$ \\
\hline \multicolumn{7}{|c|}{ Academic staff managed } \\
\hline None & 67 & 40 & 29 & 17 & 96 & 59 \\
\hline $1-5$ & 15 & 9 & 15 & 9 & 30 & 18 \\
\hline $6-10$ & 10 & 6 & 10 & 6 & 20 & 12 \\
\hline $11-15$ & 1 & 1 & 3 & 2 & 4 & 2 \\
\hline $16+$ & 5 & 3 & 11 & 7 & 16 & 10 \\
\hline \multicolumn{7}{|c|}{ Administrative staff managed } \\
\hline None & 66 & 40 & 34 & 20 & 100 & 60 \\
\hline $1-5$ & 27 & 16 & 26 & 36 & 53 & 32 \\
\hline $6-10$ & 2 & 1 & 4 & 38 & 6 & 4 \\
\hline $11-15$ & 1 & 1 & 0 & 0 & 1 & 1 \\
\hline $16+$ & 3 & 2 & 4 & 2 & 7 & 4 \\
\hline \multicolumn{7}{|l|}{ Budget holder } \\
\hline Yes & 56 & 33 & 49 & 29 & 105 & 63 \\
\hline No & 43 & 26 & 20 & 12 & 63 & 38 \\
\hline \multicolumn{7}{|c|}{ Budget amount (if holder) } \\
\hline Over $50 \mathrm{k}$ & 31 & 30 & 32 & 31 & 63 & 61 \\
\hline Below $50 \mathrm{k}$ & 24 & 23 & 17 & 17 & 41 & 39 \\
\hline
\end{tabular}

Percentage totals may not equal $100 \%$ because of rounding

individual Programme Directors...So it's much more about negotiation and facilitation and encouraging and prompting and reminding, and seeking improvements that way.

Another discussed similar strategies:

My particular strategy is to get off my backside as much as possible and talk to people, get people together...it's the mediation, it's the negotiation, it's the persuasion, it's that proper use of rhetoric in terms of getting parties together. That's the way I try to do it...

And another talked about relationship building:

I think it really comes down to personal relationships, effective personal relationships are the big things that help at all kinds of levels... What helps me a lot is having a strong relationship with key individuals in the school, because I think for associate deans, that's almost your power base really... unless you have a strong relationship with the individuals in that school, then it's very difficult, you can be very easily shut out of it. So, I've tried quite hard to build up strong relationships with key individuals so that I can get to the point of being able to have coffee with them, and just talk about general ideas... and I think that's what's worked really well.

Another interviewee explained how they tried to develop shared values within their team in order to get things done, although they admitted that they found it a difficult and slow process:

I think it's all a work in progress to tell the truth. What I try to do is work pretty closely with my program leads...I was hoping that if we could get an understanding of each other, and they understood how important my lines of communication were, then that would be alright. But there's a sort of nodding theory and then there's doing it. And I know from bitter experience that sometimes the chain has been broken because somebody didn't do the job, and sometimes that person is, has a slightly subverted ethos, 
because they don't agree with it. So, they've made it worse, so they've made an us and them kind of scenario...I've tried to get everyone to respect why, to understand why you're doing it... So, it's trying to build up a kind of ethos, where people understand freedom, but also boundaries of those freedoms...It sort of works, but it's slow... and in some respects when the senior management team make a decision...they think they've made a decision and it's just going to happen, but to actually make those things happen is a slow process. And it's actually much slower than I ever thought it would be. It's not anybody's fault. But they're big ships. The faculties are enormous organisations, big budgets and a lot of people. So, it's all slow.

And another, in response to the question, 'do you have any budgetary responsibilities?' also talked about the need for influence and persuasion in their role, without holding a budget as a 'lever':

Nope [laughter]. No levers, no levers except charm and common sense. Yeah so, we don't have any money... But I knew when I came into the role...I still struggle with it to be honest. How much can I tell people what to do, and how much can I float things as a good idea? And you know I've seen some of my colleagues in the past being very forceful, telling people what to do, which hasn't necessarily always gone down well... But that's the tricky thing about these influencing roles in leadership...

\section{Discussion}

The following discussion is organised using the study's research questions as headings and related to the theoretical framework outlined earlier, namely the concept of distributed leadership in higher education and its associated issues.

\section{How is the role of associate deans in the UK positioned in relation to university organisational structures? (RQ1)}

The results from this study show that while $38 \%$ of associate deans studied are working mainly within their faculty, the majority $(60 \%)$ are working in a joint faculty/university role and are involved with what they perceive as strategic rather than operational activities. These findings reflect the growing move in university management structures towards more thematic and project management activities being 'distributed' across institutions, in this case, via the role of an associate dean. In addition, interview data suggest that the role is often explicitly linked to an espoused policy shift towards 'distributed leadership' models within institutions. The idea is that such a role can provide a crucial link between senior leaders and academic staff. However, the findings point to the fact that distributing leadership in practice is far harder than it might look in theory due to the size and complexity of the institutions and the perceived authority that people in such positions feel they have. For example, the results showed that $58 \%$ of associate deans did not have any line management responsibilities and $38 \%$ of them were not responsible for any budget. Of those who did manage a budget, $39 \%$ were responsible only for a budget of up to $£ 50,000$, which is relatively small given the modern costs of higher education. Taken together, these findings suggest that for many associate deans, although they may be responsible for major inter-disciplinary and cross-university projects, they do not have the formal line management and budgetary controls necessary to enact important decisions with any real authority (Owens and 
Valesky 2011). Similar results have been found in a previous study exploring distributed leadership in a research-led university (Floyd and Fung 2017) and suggests that while such distributed models are increasingly espoused, any real control and accountability in term of line management responsibilities and budgets are not always relinquished from senior managers. This practice may hamper important decisions being made further down the organisational chain and points to the fact that leadership is not being fully distributed. Thus, it can be seen that while key cross-university tasks and projects are being delegated to associate deans, the real accountability and power remain at the top of the organisation (Bolden et al. 2008; Corrigan 2013). The reason for this is perhaps due to the increased external accountability pressures that higher education senior leadership teams are under (Blaschke et al. 2014). For example, one of the main dilemmas that universities face in relation to how it is organised is the tension between adopting certain common leadership structures and styles which are perceived as vital in order to survive the current market and demonstrate institutional accountability, while at the same time being expected to be innovative and entrepreneurial in their approach and outlook (Stensaker and Norgard 2001). However, our findings suggest that in order for distributed leadership models to be successful and reflect a true uncoupling (Bush 2011) from traditional vertical models of leadership (van Ameijde et al. 2009), associate deans may need to be given more control of staff and budgets to allow for real leadership distribution rather than just task delegation.

One of the ways that some of the associate deans practiced leadership without any perceived formal authority was through discursive leadership strategies (Fairhurst 2008; Fairhurst 2009; Wodak et al. 2011) which included negotiation, persuasion, relationship building, and as one said, 'charm and common sense'. Here, we can see how important the role of language and communication are to distributed leadership processes in universities in order to 'get people on board' and for change to be initiated from within rather than from the top, as has been shown in research into business organisations (Whittle et al. 2015; Wodak et al. 2011). These findings have clear implications for the development needs of people who take on such roles, as well as for the focus and content of traditional institutional leadership development programmes which are often based on outmoded top-down training models instead of drawing on more relational approaches to management development (Preston and Floyd 2016). These implications will be discussed in the concluding section of this article.

Another key finding from our study is that while associate deans are increasing in number, several of those interviewed perceived that amongst other academics and even senior leaders, the focus and purpose of the role was often unclear. Similarly, from the survey data, almost a quarter $(24 \%)$ of associate deans felt that their role was only loosely or not at all well defined. These results perhaps point to the fact that for any new distributed models to be successful, there needs to be more thought and effort put into internal communication processes to ensure all staff are clear about the purposes of such roles, how they fit within the overall organisational structures, and why they are needed. Without this clarification, academics may well remain ensconced within their traditional 'tribes and territories' (Becher and Trowler 2001) and not feel confident or willing enough to contribute to the leadership of any new cross-curricular projects being led by associate deans. Such a lack of role clarification and purpose may also anger those critics who see such cross-disciplinary initiatives as being a form of isomorphism between the public and private sector, believed to be a result of increasing neo-liberal reforms and New Public Management practices, all of which are perceived as being a threat to traditional academic values built on collegiality and traditional academic identities built on the notion of discreet academic disciplines and departments (Blaschke et al. 2014; Hartley 2009). This may well mean that institutions could lose out on the crucial 'grass roots' leadership activity of 
academics not in formal positions, which can be very influential in effecting organisational change (Kezar et al. 2011). There is also evidence to suggest that any higher education leadership practice needs to take into account the ability of individual academics to counteract the effect of leadership behaviour if they are not 'on board' with the initiative or do not see the benefits to their academic endeavour (Bryman 2007a). Taking this view, academic staff not only need to be kept fully informed and involved with such organisational changes for positive reasons, but to prevent negative actions against them which can be equally damaging, if not more so. As one associate dean said, 'And I know from bitter experience that sometimes the chain has been broken because somebody didn't do the job, and sometimes that person... has a slightly subverted ethos, because they don't agree with it.'

\section{What are the similarities and differences between associate deans working at traditional (research-led) and more modern universities (former polytechnics)? (RQ2)}

The results from this study demonstrate that there are many similarities but also clear differences between associate deans working in traditional and more modern universities. Key similarities are linked to the type of role that associate deans have in both types of universities and the cross-institutional nature of that role. Although it might have been expected to find more pronounced differences between the two university types, there appears to be many similarities (between pre-1992 and post-1992 universities) in relation to organisational leadership structures and roles at the level of the associate dean. This may suggest that there is growing convergence of value systems between the two types of universities (Floyd 2016) as they compete within an increasingly competitive and complex market-based system. This, in turn, leads to common leadership structures being adopted and thus increasing isomorphism within the sector (Stensaker and Norgard 2001).

One of the main differences that emerged from this study was linked to contracts of employment, with $72 \%$ of associate deans in post-1992 universities being in permanent contracts as compared with only $16 \%$ of those in pre-1992 universities. Similar results were found in relation to remuneration with $88 \%$ of associate deans in post-1992 universities being in a promoted senior post with associated salary against only $23 \%$ of associate deans in pre1992 universities, with the rest of them receiving an additional annual allowance (with the majority of these $(72 \%)$ receiving no more than 6 thousand pounds and $11 \%$ not receiving anything). These findings perhaps reflect the more 'managerialist' approach of new universities who see such roles as an essential aspect of 'managing' the organisation and want them therefore to be more accountable, against perhaps the more traditional, collegial management cultures of older universities where it is seen as more of a rotated academic duty that does not need formal promotion and large remuneration. However, the results from this study suggest that these practices may well change with traditional institutions being forced to adopt similar practices as their more modern counterparts, in order to adapt and survive in an increasingly competitive and international market (Holt et al. 2014).

\section{Conclusions and implications}

This article provides 'big picture' findings from the first national level study of the role of associate deans in the UK. By drawing on the concept of distributed leadership, a concept which 
is under-used and under-theorised in the higher education literature, the article makes an original and important contribution to knowledge. There are several implications that arise from this research. First, while universities are seemingly moving towards more distributed leadership models and cross-institutional project work and initiatives with associate deans apparently at the heart of this shift, there is a clear need for individuals in such roles to be given the appropriate authority - through line management and budgetary responsibilities - in order for them to make important decisions and not just recommendations. This practice might allow for a move, theoretically at least, to a genuinely distributed leadership model and allow for institutions to react with more speed and flexibility, and be more innovative and entrepreneurial in their approach to teaching, research, and knowledge transfer. If such structural changes are not possible, for example, because of internal and external accountability pressures, any training offered to associate deans should be informed from a relational perspective, drawing on discursive leadership strategies, in order to give them the skill set necessary to be able to influence and encourage staff at all levels to work towards and achieve shared organisational and professional goals. Second, our data suggest that the role of associate deans is not clearly defined across all faculties and universities and this could be problematic for the sector's future success. As an important senior role in the leadership and management of universities, the associate dean can make significant, positive contributions to teaching and learning, research, and external engagement activities. Therefore, our recommendation would be to establish a clearer definition of the associate dean role within institutions so that everyone (including senior leaders, academics, and administrative staff) is clear what and how associate deans can contribute successfully to different areas across the university. Similarly, in order to develop the concept of distributed leadership throughout an institution, all staff need to be included in any proposed organisational leadership structure change (through appropriate internal communication and discussion opportunities) so that they are aware of its importance, the reasons for its implementation, and the purpose of any new leadership roles (such as the associate dean) in leading such change. This practice may then allow staff to buy into new ways of thinking about organisational leadership in higher education and enable people not in formal leadership positions to become more involved in any decision-making processes and thus contribute positively to the leadership of the institution; indeed, academics are particularly well placed to take on this role given their high levels of education, highly developed critical thinking skills, and sense of professional responsibility. Finally, our research suggests that while there are differences in how the associate dean role is positioned between pre-1992 and post-1992 universities, there are also several similarities. This finding suggests that both sets of institutions can learn from each other about the role of the associate dean, and that cross-institutional networking might be an important step in developing the positive impact of the role in universities across the UK.

Open Access This article is distributed under the terms of the Creative Commons Attribution 4.0 International License (http://creativecommons.org/licenses/by/4.0/), which permits unrestricted use, distribution, and reproduction in any medium, provided you give appropriate credit to the original author(s) and the source, provide a link to the Creative Commons license, and indicate if changes were made.

\section{References}

Becher, T., \& Trowler, P. (2001). Academic tribes and territories. Buckingham: Society for Research into Higher Education and Open University Press.

BERA. (2011). Ethical guidelines for educational research. London: British Educational Research Association. 
Bianchini, S., Maxwell, T., \& Dovey, K. (2014). Rethinking leadership in the academy: an Australian case. Innovations in Education \& Teaching International, 51, 556-567.

Blaschke, S., Frost, J., \& Hattke, F. (2014). Towards a micro foundation of leadership, governance, and management in universities. Higher Education, 68, 711-732.

Bolden, R., Petrov, G., \& Gosling, J. (2008). Developing collective leadership in higher education. London: Leadership Foundation for Higher Education.

Bolden, R., Petrov, G., \& Gosling, J. (2009). Distributed leadership in higher education: rhetoric and reality. Educational Management Administration \& Leadership, 37(2), 257-277.

Bryman, A. (2007a). Effective leadership in higher education: a literature review. Studies in Higher Education, 32(6), 693-710.

Bryman, A. (2007b). Effective leadership in higher education: summary of findings. London: Leadership Foundation for Higher Education.

Bryman, A. (2012). Social research methods. Oxford: Oxford University Press.

Bush, T. (2011). Theories of educational leadership and management. London: Sage.

Charmaz, K. (2006). Constructing grounded theory a practical guide through qualitative analysis. London: Sage.

Coleman, M. (2005). Theories and practice of leadership. In M. Coleman \& P. Earley (Eds.), Leadership and management in education: cultures, change and context (pp. 6-24). Oxford: Oxford University Press.

Corrigan, J. (2013). Distributed leadership: rhetoric or reality? Journal of Higher Education Policy \& Management, 35(1), 66-71.

Cresswell, J. (2014). Research design. London: Sage.

Fairhurst, G. T. (2008). Discursive leadership: a communication alternative to leadership psychology. Management Communication Quarterly, 21(4), 510-521.

Fairhurst, G. T. (2009). Considering context in discursive leadership research. Human Relations, 62(11), 16071633.

Floyd, A. (2016). Supporting academic middle managers in higher education: do we care? Higher Education Policy, 29(2), 167-183.

Floyd, A., and Fung, D. (2017). Focusing the kaleidoscope: exploring distributed leadership in an English university. Studies in Higher Education, 42(8), 1488-1503.

Flumerfelt, S., \& Banachowski, M. (2011). Understanding leadership paradigms for improvement in higher education. Quality Assurance in Education, 19(3), 224-247.

Gall, M. D., Gall, J. P., \& Borg, W. (2007). Eduational research-an introduction. Boston: Pearson.

Gehlbach, H., \& Brinkworth, M. E. (2011). Measure twice, cut down error: a process for enhancing the validity of survey scales. Review of General Psychology, 15(4), 380-387.

Gronn, P. (2008). The future of distributed leadership. Journal of Educational Administration, 46(2), 141-158.

Hartley, D. (2009). Education policy, distributed leadership and socio-cultural theory. Educational Review, 61(2), 139-150.

Holt, D., Palmer, S., Gosper, M., Sankey, M., \& Allan, G. (2014). Framing and enhancing distributed leadership in the quality management of online learning environments in higher education. Distance Education, 35(3), 382-399.

Kezar, A., Bertram Gallant, T., \& Lester, J. (2011). Everyday people making a difference on college campuses: the tempered grassroots leadership tactics of faculty and staff. Studies in Higher Education, 36(2), 129-151.

Lichtman, M. (2013). Qualitative research in education: a user's guide, thousand oaks. California: Sage.

Lumby, J. (2013). Distributed leadership: the uses and abuses of power. Educational Management Administration \& Leadership, 41(5), 581-597.

Mayrowetz, D. (2008). Making sense of distributed leadership: exploring the multiple usages of the concept in the field. Educational Administration Quarterly 44(3), 424-435.

Miles, M. B., \& Huberman, A. M. (1994). Qualitative data analysis. California: Sage Publications Ltd..

Northouse, P. G. (2013). Leadership: theory and practice. London: Sage.

Owens, R. G., \& Valesky, T. C. (2011). Organizational behavior in education. New Jersey: Pearson.

Pepper, C., \& Giles, W. (2015). Leading in middle management in higher education. Management in Education, 29(2), 46-52.

Preston, D., \& Floyd, A. (2016). Supporting the role of associate dean in universities: an alternative approach to management development. Higher Education Quarterly, 70(3), 264-280.

Preston, D., \& Price, D. (2012). 'I see it as a phase: I don't see it as the future': academics as managers in a UK university. Journal of Higher Education Policy and Management, 34(4), 409-419.

Punch, K. (2014). Introduction to social research. London: Sage.

Spillane, J. P., Halverson, R., \& Diamond, J. B. (2007). Towards a theory of leadership practice: a distributed perspective. Journal of Curriculum Studies, 36(1), 3-34.

Stensaker, B., \& Norgard, J. D. (2001). Innovation and isomorphism: a case-study of university identity struggle 1969-1999. Higher Education, 42, 473-492. 
Torrance, D. (2013). Distributed leadership: challenging five generally held assumptions. School Leadership \& Management, 33(4), 354-372.

van Ameijde, J. D. J., Nelson, P. C., Billsberry, J., \& van Meurs, N. (2009). Improving leadership in higher education institutions: a distributed perspective. Higher Education, 58(6), 763-779.

Whittle, A., Housley, W., Gilchrist, A., Mueller, F., \& Lenney, P. (2015). Category predication work, discursive leadership and strategic sensemaking. Human Relations, 68(3), 377-407.

Wodak, R., Kwon, W., \& Clarke, I. (2011). 'Getting people on board': discursive leadership for consensus building in team meetings. Discourse \& Society, 22(5), 592-644.

Woods, P. A., Bennett, N., Harvey, J. A., \& Wise, C. (2004). Variabilities and dualities in distributed leadership. Educational Management Administration \& Leadership, 32(4), 439-457. 